\title{
Physico-chemical treatment of waste water contaminated with heavy metals in the industry of metallic coatings
}

\author{
Jacipt A.R. VALENCIA ${ }^{\text {1) AE }}$, Jordi P. GONZÁLEZ ${ }^{2) ~ B C E}$, \\ Iris JIMENEZ-PITRE ${ }^{3) ~ F}$, Geomar MOLINA-BOLÍVAR ${ }^{4)}$ DF $ه$
}

1) orcid.org/0000-0002-2030-4904; University of Pamplona, Faculty of Engineering and Architecture, GIAAS research group. Colombia

2) orcid.org/0000-0002-7468-6741; Colombian School of Engineering Julio Garavito, Civil Engineering Program, Bogota, Colombia

3) orcid.org/0000-0003-0575-3717; University of La Guajira, Faculty of Science Basic and Applicated, BIEMARC, Colombia

4) orcid.org/0000-0001-6380-379X; University of La Guajira, Faculty of Science Basic and Applicated, BIEMARC, Colombia; e-mail: gmolina@uniguajira.edu.co.

For citation: Valencia J.A.R., González J.P., Jimenez-Pitre I., Molina-Bolívar G. 2019. Physico-chemical treatment of waste water contaminated with heavy metals in the industry of metallic coatings. Journal of Water and Land Development. No. 43 (X-XII) p. 171-176. DOI: 10.2478/jwld-2019-0075.

\begin{abstract}
This investigation was undertaken to determine the optimum conditions for physical-chemical treatment of waste water contaminated with heavy metals in the industry of metallic coatings. The industry uses substances such as: inorganic acids, alkalis, acidic and alkaline metal salts, that has a high water demand in the processes of flushing and cleaning the parts to be coated. According to the preliminary characterization of samples and reported in the literature theory, physico-chemical process was implemented for the removal of contaminants that consisted in chemical oxidation of CN-ions, followed by chemical precipitation made next to a coagulation/flocculation and subsequent adsorption on activated coal. Laboratory scale tests showed the optimal conditions of treatment including chemical oxidation by the addition of $4.15 \mathrm{~cm}^{3}$ of $\mathrm{H}_{2} \mathrm{O}_{2}$ (30\%) per gram of $\mathrm{CN}$, chemical precipitation with $\mathrm{NaOH}$ to a $\mathrm{pH}$ of 12 , followed by coagulation/flocculation with $\mathrm{Fe}_{2}\left(\mathrm{SO}_{4}\right)_{3}$ at a speed of $135 \mathrm{rpm}$ for $3 \mathrm{~min}$ and $20 \mathrm{rpm}$ for $20 \mathrm{~min}$ and finally the addition of $1.0 \mathrm{~g}$ of adsorbent previously activated at $700^{\circ} \mathrm{C}$. From this study, it is clear that the adsorption on activated carbon is highly efficient in the removal of heavy metals from industrial waste water from electroplating. However, it is also clear that the parallel application of the treatments, shown here, is more effective to completely remove contaminants such as lead, nickel, silver, and copper at laboratory scale, so it is recommended the simultaneous use of these physico-chemical processes.
\end{abstract}

Key words: coagulation-flocculation, heavy metals, industrial waste water, metallic coatings, precipitation

\section{INTRODUCTION}

The industrial development has caused significant increases in the number of production processes that generate chemical or hazardous pollutants, or chemical compounds that are required as raw materials or intermediate inputs. These processes are accompanied by increasing levels of air pollutants emissions, water pollutants and a high incidence of dangerous waste; the information about the physical and chemical characteristics of the substances used in production processes can plumb to improper han- dling by the operators and also could produce an environmental emergency, leaking, spill or explosion. In order to take action, both preventive and corrective, we made an environmental risk assessment in the industry of metallic coatings [MolinA-Gallegos 2012]. The impurities that can be found in effluent from numerous sources (domestic and industrial), of different nature and concentration, and its treatment can realize by different ways [BEDLA, DACEWICZ 2019; DOMAŃSKA et al. 2019]; reagents that are frequently used in the processes are: inorganic acids, alkalis, acidic and alkaline metal salts, metal oxides, solvents, pol- 
ishes, surfactants, among others; as a result, residues of these substances are also commonly found in sewage, even groundwater [MALEK et al. 2019], thanks to the drag of chemicals in the corresponding to the process rinses [TEJADA et al. 2014].

The pollution of industrial waste water with heavy metals is one of the most serious environmental problems that occurs today [BOLAÑOS et al. 2014]. Most of these products are hazardous substances, persistent and bioaccumulative, but the features mainly toxic confers the management of metals such as chromium $(\mathrm{Cr})$, plumb $(\mathrm{Pb})$, cadmium $(\mathrm{Cd})$, nickel $(\mathrm{Ni})$, zinc $(\mathrm{Zn})$, silver $(\mathrm{Ag})$, among others, which make this industry is one of the most dangerous for the environment, since contaminants such as heavy metals are not biodegradable, exhibit high solubility in aquatic systems and can be absorbed by living organisms [TEJADA-TOVAR et al. 2015]. Once they enter the food chain can be accumulated in the human body causing serious health problems [LONDOÑO-FRANCO et al. 2016].

The removal and/or recovery of metals has been practiced for more than 5000 years; have developed an arsenal of separation technologies both to reduce the amount of waste water generated to improve the quality of the treated effluent [TEJADA-TOVAR et al. 2015]. For the latter are methods of removing conventional and chemical precipitation, processes of coagulation-flocculation, flotation, adsorption, oxidation, among others, but before you opt for any of these methods must be analysed using the parameters such as the initial concentration of pollutants and the volume of effluent to be treated, since in galvanization plants qualitative and quantitative variations of pollutants are common due to the wide variety of coating processes that are given to the surface of a metal [CARDONA 2014]. It is generally recommended the separation of the waste water flows, according to their composition, in partial flows: waste water acidic, alkaline waste water, waste water with cyanide, waste water from the chrome, waste water from the degreasing. [FREIRE-ESPÍN 2012]. The advantage of not mixing different partial flows is the possibility of a specific treatment of waste water and sludge generation monometallic that can be retrieved more easily [DELGADILLO et al. 2010; MAZARIEGO-ROBLES 2017].

The aim of this research is the evaluate the removal to heavy metals (arsenic - As, chromium $-\mathrm{Cr}$, cupper $-\mathrm{Cu}$, silver - Ag, nickel - $\mathrm{Ni}$ and $\mathrm{Pb}$, plumb) of economic interest of the waste water of the electroplating plant Argentis collection's Ltda, with different physico-chemical treatments as a synergic system.

\section{MATERIALS AND METHODS}

The samples were collected in the electroplating plant of a company located in the city of Cucuta, Norte de Santander, Colombia, dedicated to the production of coated in silver accessories. The sampling was carried out under the principles of custody of collection, handling and transport of samples, following the recommendations of standard methods for the analysis of drinking and waste water as contemplated in the RAS 2000 [Minvivienda 2000]; for this, one sampled was carry out in the plant, between Janu- ary and February 2010, and samples was taken with clean plastic bottles with a $1 \mathrm{dm}^{3}$ of capacity. The literature recommends the separation of the waste water flows and the partial treatment of these in electroplating, due to the complexity of processes and the large amount of chemicals handled, for this reason, two samples of $1 \mathrm{dm}^{3}$ were taken from each of the contiguous rinses the tanks of coating, to analyse a possible obtaining sludge metal, as these contain different pollutants by the drag of chemicals from the immediately preceding [FREIRE-ESPÍN 2012]. In addition, samples of the storage tank waste water treatment of the company where they are all residues of the process, without prior separation of the same and are stored until $5000 \mathrm{dm}^{3}$, in order to provide treatment discontinued in this water.

In synthesis, there was a single sampling in the storage tank of waste water in where all waste from the processes and samples were also taken from the subsequent rinses baths: chemical degreasing, varnish, metallic coating: copper alkaline $\mathrm{pH}$, copper acid $\mathrm{pH}$, palladium - tin $\left(\mathrm{SnO}_{2}\right)$, pre-silver and silver.

The concentration of metals was determined by atomic absorption spectrometry using an Atomic Absorption Spectrophotometer (AAS) Perkin Elmer Analyst 300 with hollow cathode lamps $\mathrm{As}, \mathrm{Cu}, \mathrm{Cr}, \mathrm{Ni}, \mathrm{Pb}$, and $\mathrm{Ag}$. The determination of silver in the water samples was performed by a metric method (since I didn't have hollow cathode lamp corresponding to this element), using potassium thiocyanate $\mathrm{KSCN}$ (Carlo Erba ${ }^{\circledR}$ ) $0.101 \mathrm{M}$ as the titrant and iron (III) chloride $-\mathrm{FeCl}_{3}\left(\mathrm{Merck}^{\circledR}\right) 0.037 \mathrm{M}$ as an indicator [BUDAVARI 1989; VERARDO et al. 1990]. The determination of the metals was performed before and after each treatment, and concentrations values are expressed in average, and removal are expressed in percent (\%).

\section{CHEMICAL PRECIPITATION FOLLOWED BY COAGULATION/FLOCCULATION (P-C/F) WITH IRON (III) SULPHATE}

Prior to these analyses, it was carried out the oxidation of cyanide content in the samples with hydrogen peroxide $\left(\mathrm{H}_{2} \mathrm{O}_{2}\right)$ at the $\mathrm{pH}$ of 11.45 due to interference that these had to form very stable complexes with metals, which does not make it possible precipitation. The experiments started with a $\mathrm{pH}$ adjustment to 12 with sodium hydroxide (Carlo Erba $\left.^{\circledR}\right)$, for the chemical precipitation in alkaline medium of the preliminarily treated samples with $\mathrm{H}_{2} \mathrm{O}_{2}$, in an In lab Multi Level 1 equipment [VERARDO et al. 1990]. The tests were conducted on a universal bottle probe tool, using as a coagulant/flocculant of iron (III) sulphate $\left(\mathrm{Fe}_{2}\left(\mathrm{SO}_{4}\right)_{3}\right)$ [BUDAVARI 1989]. Previously determined the best coagulant/flocculant, optimum $\mathrm{pH}$ as well as the speed on the tool, the universal bottle probe. The samples were restive initially for $3 \mathrm{~min}$ at $135 \mathrm{rpm}$ and then to $20 \mathrm{rpm}$ up to complete $20 \mathrm{~min}$. Finally left to settle the corresponding solid in a space of 30 to $40 \mathrm{~min}$.

\section{ADSORPTION ON ACTIVATED CARBON (A)}

For the study of adsorption on activated carbon samples were used in the previous step and decanted samples without any treatment. A quantity of $1.0 \mathrm{~g}$ was used from 
the adsorbent for each testing, to $700^{\circ} \mathrm{C}$ previously activated by $40 \mathrm{~min}$, added to $100 \mathrm{~cm}^{3}$ of sample with constant stirring for $15 \mathrm{~min}$ and finally let itself interact the system lido-liquid by a space of 12 hours.

\section{RESULTS AND DISCUSSION}

The importance of taking samples from the rinses is, in fact, that even when these are part of the processes of coatings, are often discharged into the storage tank to be sufficiently contaminated as not to exercise their role of cleaning, and as such each rinse carries specific pollutants (not only heavy metals), therefore the idea is not to mix up pollutants, but on the contrary purveyors to a specific treat-
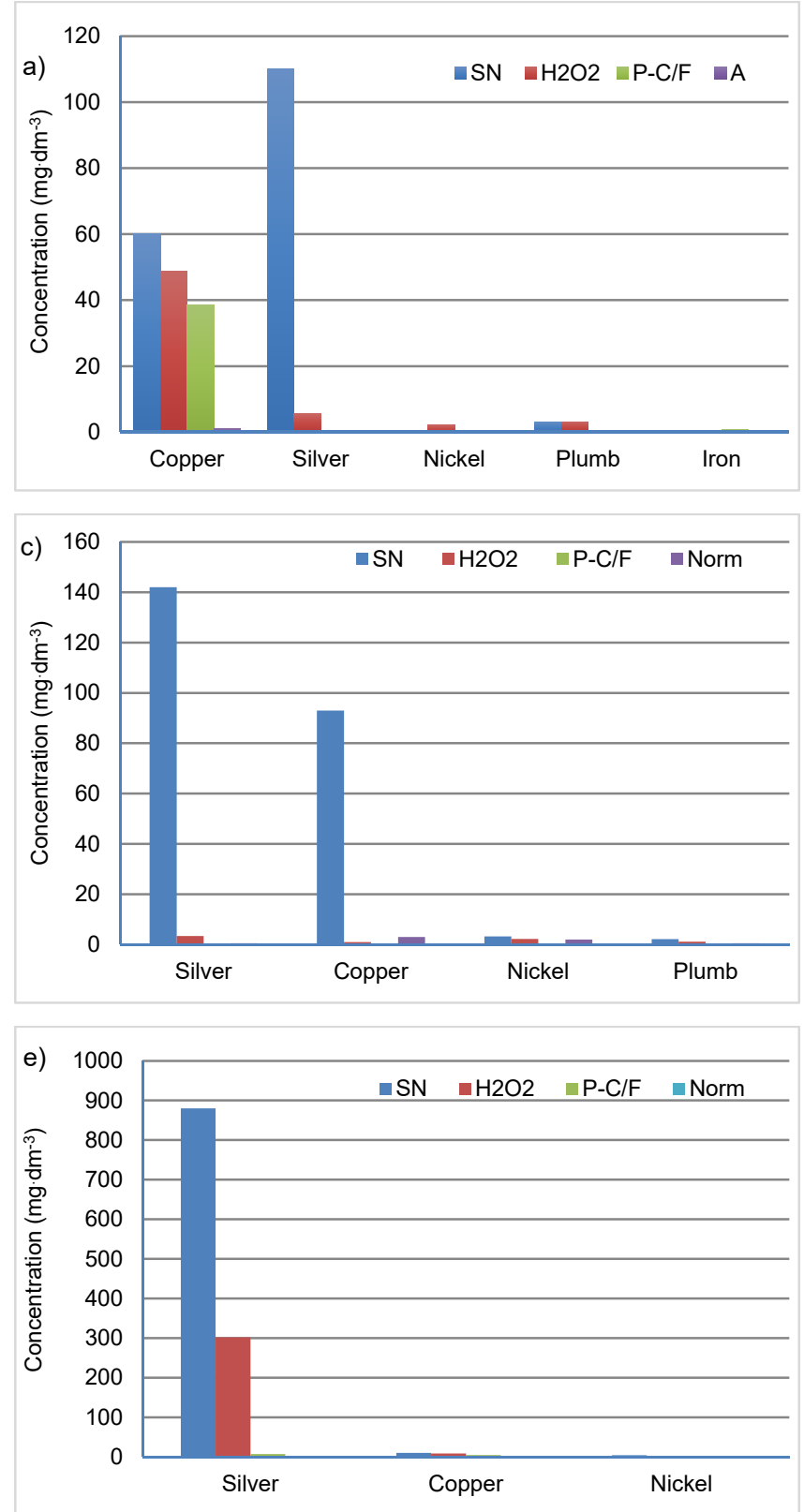

ment to make it less complex this process and even the possibility of recovering some substances of economic interest. The determination of $\mathrm{Cr}$ and As yielded no detectable results for any of the samples. The concentration of $\mathrm{Cu}, \mathrm{Ni}, \mathrm{Pb}$ and $\mathrm{Ag}$ are shown in the Figure 1a for samples of the storage tank. The optimal dose of $\mathrm{Fe}_{2}\left(\mathrm{SO}_{4}\right)_{3}$ was 75 $\mathrm{cm}^{3}$ for sample volumes of $250 \mathrm{~cm}^{3}$.

The adsorption process was implemented in consequence that the percentage of removal of copper (Fig. 1a) after P-C/F (36.20\%) was not effective enough so that samples fall within the norm established by Colombian Law (Decreto No. 1594, art 74) for this metal, but in the treatment with the percentage of adsorption of $98.01 \%$ removal was with which that goal was achieved.
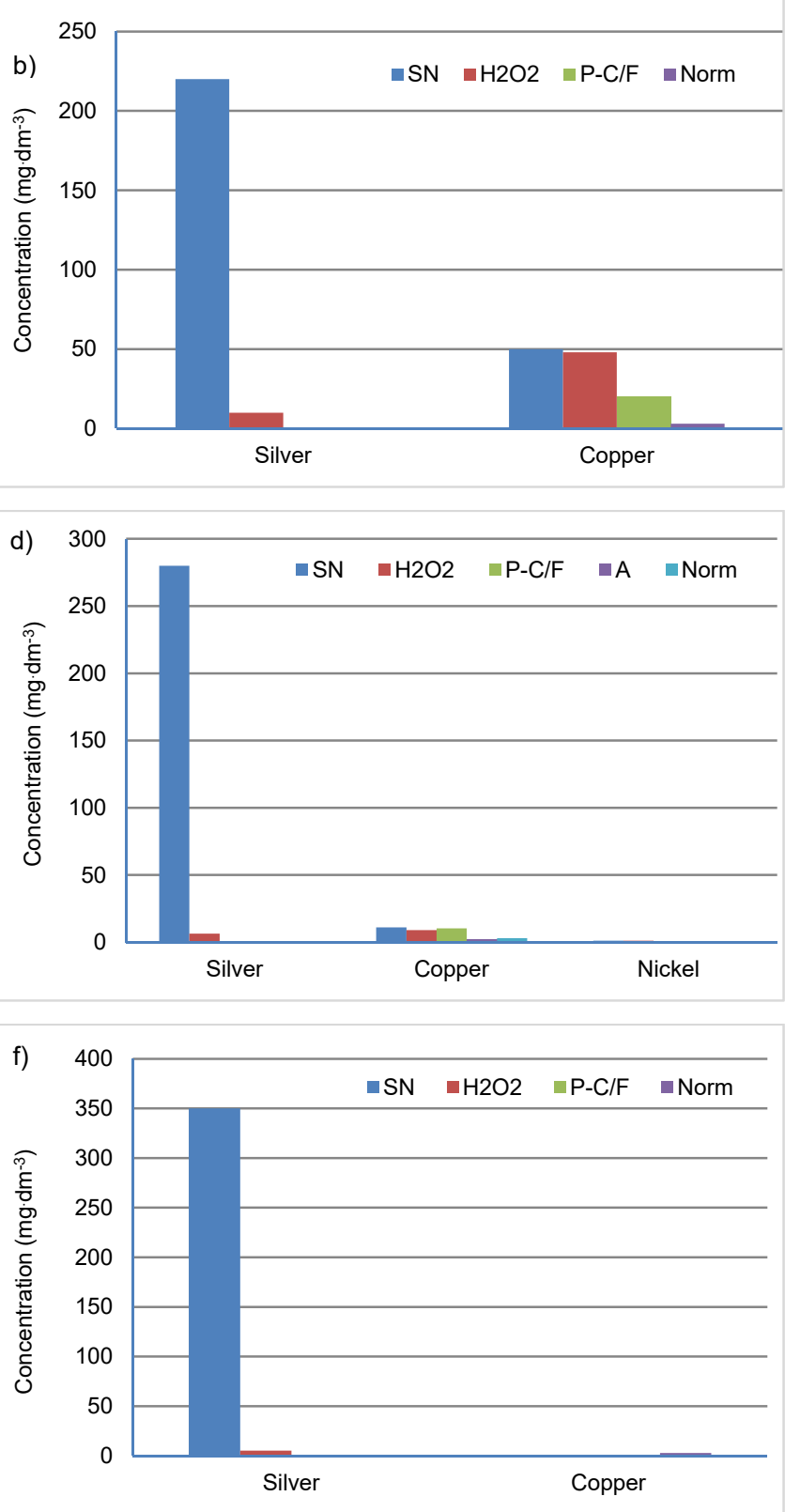

Fig. 1. Decrease of metals present: a) in the storage tank, b) in the rinse of copper alkaline $\mathrm{pH}, \mathrm{c}$ ) in the copper rinse acid $\mathrm{pH}, \mathrm{d}$ ) in the rinse palladium tin, e) in the pre-rinse of silver, $\mathrm{f}$ ) in the rinse varnish chemical; $\mathrm{SN}=$ without treatment, $\mathrm{H}_{2} \mathrm{O}_{2}=$ prior oxidation of cyanide in the sample with hydrogen peroxide, $\mathrm{P}-\mathrm{C} / \mathrm{F}=$ chemical precipitation followed by coagulation flocculation, $\mathrm{A}=$ adsorption on activated carbon (determination not performed in these samples), Norm = values in regulation law in Colombia; 
On the contrary, the silver presented a $94.85 \%$ of removal in the oxidation of cyanide with $\mathrm{H}_{2} \mathrm{O}_{2}$, even though it was intended to oxidize only the cyanide ion present in the samples, but in this procedure also adjusted the $\mathrm{pH}$ (data not reported), which facilitated the precipitation of metals, in the case of the metal mentioned with a high percentage of mine, which was supplemented by chemical precipitation-coagulation/flocculation. On the other hand, the results of the analysis carried out to the rinses after each bath are the following.

Copper rinse alkaline pH. As can be seen in Figure $1 \mathrm{~b}$ the metals in this rinse are silver and copper, the percentages of mine achieved for these after all treatment were for the $100 \%$ silver and copper in tickets $87.28 \%$. For the latter the removal was achieved thanks to the adsorption process carried out at the end. The optimal dose of $\mathrm{Fe}_{2}\left(\mathrm{SO}_{4}\right)_{3}$ was $60 \mathrm{~cm}^{3}$ for a volume of samples of $250 \mathrm{~cm}^{3}$.

Copper rinse acid pH. The optimal dose of $\mathrm{Fe}_{2}\left(\mathrm{SO}_{4}\right)_{3}$ was $50 \mathrm{~cm}^{3}$ for sample volumes of $200 \mathrm{~cm}^{3}$. For the treatment of this was not necessary to rinse the adsorption process, as shown in Figure 3 the removal was highly effective from the peroxide to the P-C/F. It shifted the $99.97 \%$ copper and silver completely. In this rinse, concentrations of nickel and plumb the order of 0.117 and $1.136 \mathrm{mg} \cdot \mathrm{dm}^{-3}$, respectively, being these very low concentrations, however, it should be noted that even in small amounts the two metals are highly toxic and dangerous (Fig. 1c).

Rinse palladium tin. The optimal dose of $\mathrm{Fe}_{2}\left(\mathrm{SO}_{4}\right)_{3}$ was $40 \mathrm{~cm}^{3}$ for sample volumes of $170 \mathrm{~cm}^{3}$. Figure $1 \mathrm{~d}$ shows that the concentration of copper in the sample, although important, is low in comparison with the previous rinses (only $19.77 \mathrm{mg} \cdot \mathrm{dm}^{-3}$ ), however, as well as all the rinses the metal with a higher concentration is the silver. At the end of the treatment the three metals present fall within the rules of pollutant removal with the treatment carried out.

Pre-rinse silver. The optimal dose of $\mathrm{Fe}_{2}\left(\mathrm{SO}_{4}\right)_{3}$ was $75 \mathrm{~cm}^{3}$ for sample volumes of $200 \mathrm{~cm}^{3}$. As can be seen in Figure 1e, in the treatment as with the copper rinse acid $\mathrm{pH}$, it was necessary to implement adsorption on activated carbon since with the $\mathrm{P}-\mathrm{C} / \mathrm{F}$ is removed the metals.

The concentration of copper and nickel is negligible while the concentration of silver is $888.22 \mathrm{mg} \cdot \mathrm{dm}^{-3}$ concentration, which is reasonable since the sample comes from a rinse to where the drag of chemicals from a bath basically composed of silver salts.

Rinse silver. The optimal dose of $\mathrm{Fe}_{2}\left(\mathrm{SO}_{4}\right)_{3}$ was 40 $\mathrm{cm}^{3}$ for sample volumes of $100 \mathrm{~cm}^{3}$. This rinse presented a concentration of $1246.97 \mathrm{mg} \cdot \mathrm{dm}^{-3}$ of silver and just 3.623 $\mathrm{mg} \cdot \mathrm{dm}^{-3}$ of copper as shown in Figure $1 \mathrm{f}$, but even so, it became necessary to perform the $\mathrm{P}-\mathrm{C} / \mathrm{F}$. The process of removal was one of the easiest to not possessing the interference that provide other metals for the precipitation process will take place.

Rinse chemical varnish. For this sample was not necessary to apply $\mathrm{P}-\mathrm{C} / \mathrm{F}$, since in the pre-treatment (with $\mathrm{H}_{2} \mathrm{O}_{2}$ ) was removed, the concentration of metals as shown in the following. It should be noted that not all the shower in the electroplating processes presented in its formulation silver salts, for example, the copper shower acid $\mathrm{pH}$, palla- dium, the bath of varnish chemical, but from these rinses contain considerable concentrations of the precious metal, as not all bath contain copper, therefore one can speak of a possible contamination of the bath within the process.

Rinse degreaser. The samples taken from the rinse tank after the degreaser showed no detectable concentrations of any of the metals analysed. The result is acceptable, since the bath degreaser that use within the processes to clean the parts to be coated is not composed of any salt of the metals analysed in this study and also should not be contaminated by these. Additional to the previous trials, we also evaluated the reduction of pollutants to perform adsorption on activated carbon in some samples without prior treatment. As shown in Figure 2 we analysed the waste water of the storage tank of pollutants, the waters of the palladium rinse and rinse of alkaline copper. These were chosen to perform adsorption on be those rinses that needed this process after treatment with $\mathrm{P}-\mathrm{C} / \mathrm{F}$ to remove acceptable percentages of metals present in the samples.

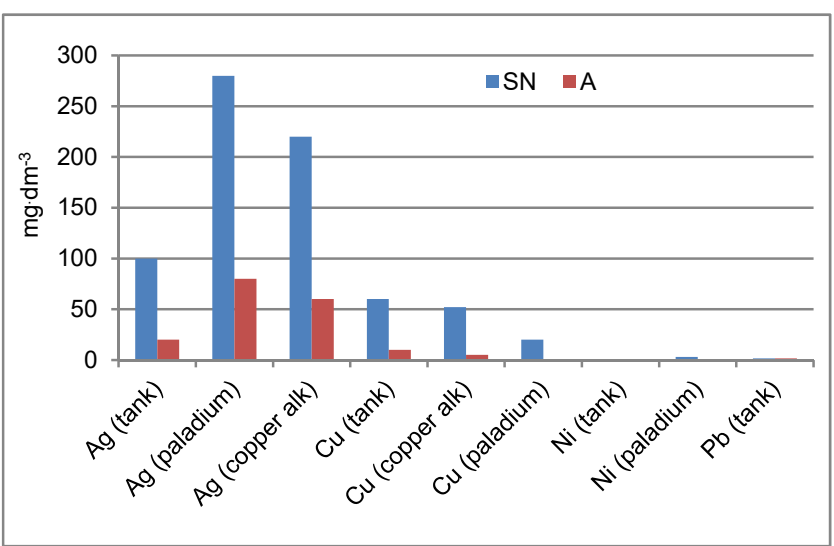

Fig. 2. Decrease in metals by adsorption for different types of samples without prior treatment; $\mathrm{SN}=$ without treatment,

$\mathrm{A}=$ adsorption on activated carbon; source: own study.

It can be observed a considerable decrease in metal concentrations, the removal of silver ranged between 65 and $70 \%$ for samples of the storage tank, rinsing of palladium and rinsing the alkaline copper ( $\%$ of silver mine very similar between the samples), the copper in the storage tank was removed in a $85 \%, 80 \%$ in the alkaline copper rinse and $97.98 \%$ in the palladium, nickel is removed completely in the samples analysed and finally plumb only in a $12.91 \%$ even when present in low concentrations, however this removal for none of the metals does not exceed the obtained using the above processes sequentially and neither leaves the metals within the permissible limits.

\section{CONCLUSIONS}

In the results it can be seen that the metals present in greater concentration on the storage tank are copper $(>50$ $\left.\mathrm{mg} \cdot \mathrm{dm}^{-3}\right)$ and silver $\left(>100 \mathrm{mg} \cdot \mathrm{dm}^{-3}\right)$, as in most of the rinsing in where silver is presented in even in concentrations of $1246.97 \mathrm{mg} \cdot \mathrm{dm}^{-3}$, therefore is left open the possibility of recovering this metal of high economic interest of the rinses after each coating bath instead of mixing it with 
the rest of pollutants from the processes that go to the storage tank for subsequent treatment.

On the other hand, nickel is present in the samples of copper rinses acid $\mathrm{pH}$, palladium and pre-silver, while the plumb in copper rinse acid $\mathrm{pH}$; the two metals at low concentrations $\left(<10 \mathrm{mg} \cdot \mathrm{dm}^{-3}\right)$; therefore, it is concluded that nickel and plumb found in samples of the storage tank of waste comes specifically from the showers of the procedure.

Most important are the percentage of removal, in $\mathrm{Cu}$ was $98.01 \%$ with the activate carbon absorption treatment, and $99.97 \%$ of removal together with the $\mathrm{Ag}$ in the $\mathrm{P}-\mathrm{C} / \mathrm{F}$ treatment of the copper rinse acid $\mathrm{pH}$ samples; $\mathrm{Ag}$ presents a $94.85 \%$ of removal with the oxidation of cyanide with $\mathrm{H}_{2} \mathrm{O}_{2}$. In the active carbon absorption treatment, the percent of removal was total to $\mathrm{Ni}$, and high to $\mathrm{Cu}$ and $\mathrm{Ag}(>60 \%)$, but very low to the plumb (12.91\%); nevertheless, only this process not allowed obtain values below the regulations of Colombia, with exception of $\mathrm{Ni}$.

Implemented too many process of consecutive way to eliminate contaminants represents high cost of operation, but to waste water treatment is necessary because not all metal contaminants are removal with only one treatment, and this significant an important process to reduce the environmental contamination and risk of toxicity to worker staff.

\section{ACKNOWLEDGEMENTS}

The authors thank the University of Pamplona, the School of Engineering "Julio Garavito" and the University of La Guajira for the unconditional support for conducting collaborative research and special in the elaboration of this scientific article.

\section{REFERENCES}

Bedla D., Dacewicz E. 2019. Data clustering analysis in the assessment of wastes using in the sewage filtration. Journal of Water and Land Development. No. 41 p. 31-36. DOI 10.2478/jwld-2019-0024.

Bolaños E., Tejada C., Ruíz V. 2014. Remediación de aguas contaminadas con cromo utilizando diferentes biomateriales residuales [Remediation of chromium-contaminated water using different waste biomaterials]. Revista Ciencias e Ingeniería al Día. Vol. 9. No. 1 p. 25-42.

BUDAVARI S. 1989. The Merck index, an encyclopedia of chemical drug, and biologicals. Rahway, N.J., U.S.A. Merck. ISBN 9780911910001 pp. 31.

CARDONA S. 2014. Evaluación fisicoquímica por el método de adsorción-coagulación-floculación para la remoción de colorantes del efluente del área de procesos industriales de la empresa Textil Co\&Tex SAS [Physicochemical evaluation by the adsorption-coagulation-flocculation method for the removal of effluent dyes from the industrial process area of the company Textil Co\&Tex SAS]. PhD Thesis. Pereira. Universidad Tecnológica de Pereira pp. 67.

Decreto No. 1594 del 26 de Junio de 1984. Usos del agua y residuos líquidos [Decree 1594 from June 26, 1984. Uses of water and liquid waste]. Diario official. No. 41465 [online].
[Access 1.03.2019]. Available at: http://www.ideam.gov.co/ documents/24024/36843/Dec 1594 1984.pdf/aacbcd5d-fed84273-9db7-221d291b657f

Delgadillo O., Camacho A., Perez L., Andrade M. 2010. Depuración de aguas residuales por medio de humedales artificiales [Wastewater treatment by means of artificial wetlands]. Ser. Tecnica. Cochabamba, Bolivia. Centro AGUA. ISBN 97899954766-2-5 pp. 102.

DomańSKa M., Boral A., Hamal K., KuŚNierz M., ŁomoTOWSKI J., PŁAZA-OżóG P. 2019. Efficiency of municipal wastewater treatment with membrane bioreactor. Journal of Water and Land Development. Vol. 41 p. 47-54. DOI 10.2478/jwld-2019-0026.

FREIRE ESPín P. 2012. Análisis y evaluación de un sistema de tratamiento de aguas residuales para la Empresa TEIMSAAmbato [Analysis and evaluation of a wastewater treatment system for the TEIMSA-Ambato Company]. B.S. Thesis. Chimborazo. Escuela Superior Politécnica de Chimborazo, Ecuador pp. 87.

Londoño-Franco L., Londoño-MuÑoz P., MuÑoz-García F. 2016. Los riesgos de los metales pesados en la salud humana $y$ animal [The risks of heavy metals on human and animal health]. Biotecnología en el Sector Agropecuario y Agroindustrial. Vol. 14. No. 2 p. 145-153. DOI 10.18684/BSAA (14)145-153.

MaleK A., Kahoul M., Bouguerra H. 2019. Groundwater's physicochemical and bacteriological assessment: Case study of well water in the region of Sedrata, North-East of Algeria. Journal of Water and Land Development. Vol 41. No. 1 p. 91-100. DOI 10.2478/jwld-2019-0032.

MAZARIEGO Robles D. 2017. Elementos químicos en la vegetación de la planta de tratamiento de agua residual de la UAAAN [Chemical elements in the vegetation of the UAAAN wastewater treatment plant]. [Work presented as a partial requirement to obtain the title of: agricultural and environmental engineer]. Saltillo, Mexico. Universidad Autonoma Agraria Antonio Narro pp. 46

Minvivienda 2000. Reglamento técnico para el sector de agua potable y saneamiento básico - RAS [Technical regulation for the sector of drinking water and basic sanitation - RAS] [online]. Colombia: Resolución. [Access 1.03.2019]. Available at: http://www.minvivienda.gov.co/Resoluciones Agua/1096\%20-\%202000.pdf

Molina Gallegos V. 2012. Minimización del riesgo ambiental en la industria de galvanoplastia [Minimizing environmental risk in the gal-vanoplasty industry]. PhD Thesis. México. Instituto Politécnico Nacional, México pp. 101.

Tejada C., QuiÑonez E., PeÑa M. 2014. Contaminantes emergentes en aguas: Metabolitos de fármacos. Una revisión [Emerging water pollutants: Drug metabolites. A review]. Revista Facultad de Ciencias Básicas. Vol. 10. No. 1 p. 80 101. DOI 10.18359/rfcb.341.

Tejada-Tovar C., Villabona-Ortiz A., Garcés-Jaraba L. 2015. Adsorción de metales pesados en aguas residuales usando materiales de origen biológico [Adsorption of heavy metals in wastewater using bio-based materials]. TecnoLógicas. Vol. 18. No. 34 p. 109-123.

Verardo D., Froelich P., Mcintyre A. 1990. Determination of organic carbon and nitrogen in marine sediments using the Carlo Erba NA-1500 Analyzer. Deep Sea Research. Part A. Oceanographic Research Papers. Vol. 37. No. 1 p. 157-165. 


\section{Jacipt A.R. VALENCIA, Jordi P. GONZÁLEZ, Iris JIMENEZ-PITRE, Geomar MOLINA-BOLÍVAR}

Fizykochemiczne oczyszczanie ścieków zanieczyszczonych metalami ciężkimi w przemyśle metalowym

\section{STRESZCZENIE}

Badania podjęto celem ustalenia optymalnych warunków fizycznego i chemicznego oczyszczania ścieków z galwanizerni. Zakłady takie wykorzystują kwasy nieorganiczne, alkalia i sole metali o odczynie kwasowym bądź zasadowym. Ponadto zużywają one dużo wody w procesie oczyszczania i płukania pokrywanych metalami elementów. Na podstawie wstępnej charakterystyki próbek i danych literaturowych wdrożono fizyczny i chemiczny proces usuwania zanieczyszczeń, który polegał na chemicznym utlenianiu jonów $\mathrm{CN}$ oraz chemicznym wytrącaniu, koagulacji/flokulacji oraz adsorpcji na węglu aktywnym. Testy w skali laboratoryjnej wykazały, że optymalne warunki oczyszczania obejmowały chemiczne utlenianie dzięki dodatkowi $4,15 \mathrm{~cm}^{3} \mathrm{H}_{2} \mathrm{O}_{2}(30 \%)$ na gram $\mathrm{CN}$, chemiczne strącanie $\mathrm{NaOH}$ do $\mathrm{pH}$ 12, a następnie koagulację/ flokulację z prędkością $135 \mathrm{obr} \cdot \mathrm{min}^{-1}$ przez $3 \mathrm{~min}$ i $20 \mathrm{obr} \cdot \mathrm{min}^{-1}$ przez $20 \mathrm{~min}$ oraz dodatek $1,0 \mathrm{~g}$ adsorbentu aktywowanego wstępnie $\mathrm{w} 700^{\circ} \mathrm{C}$. Badania wykazały, że adsorpcja na węglu aktywnym jest wysoce efektywna w usuwaniu metali ciężkich ze ścieków galwanizerskich. Równoległe stosowanie zabiegów przedstawionych w pracy zapewnia jeszcze większą efektywność w całkowitym usuwaniu ołowiu, niklu, srebra i miedzi w skali laboratoryjnej. Dlatego równoczesne stosowanie tych zabiegów jest zalecane w praktyce.

Słowa kluczowe: galwanizowanie, koagulacjalflokulacja, metale ciężkie, ścieki przemystowe, wytracanie 